\title{
COMMENTARY
}

\section{Ligands of the peroxisome proliferator-activated receptor- $\gamma$ and heart failure}

\author{
${ }^{*, 1}$ C. Thiemermann
}

${ }^{1}$ The Department of Experimental Medicine, Nephrology and Critical Care, William Harvey Research Institute, St Bartholomew's and The Royal London School of Medicine and Dentistry, Charterhouse Square, London EC1M 6BQ

Peroxisome proliferator-activated receptors (PPARs) are members of the nuclear hormone receptor superfamily of ligand-activated transcription factors that are related to retinoid, steroid and thyroid hormone receptors. The PPAR subfamily comprises of three members, PPAR- $\alpha$, PPAR- $\beta$ and PPAR- $\gamma$. There is good evidence that ligands of PPAR $-\gamma$, including certain thiazolinediones, reduce myocardial tissue injury and infarct size. The use of PPAR- $\gamma$ agonists in the treatment of heart failure is, however, controversial.

British Journal of Pharmacology (2004) 141, 1-3. doi:10.1038/sj.bjp.0705586

Keywords: PPAR; nuclear-receptors; myocardial infarction; myocardial ischaemia

Abbreviations: MCP-1, monocyte chemoattractant protein-1; NIDDM, non-insulin-dependent diabetes mellitus; PGA 1 , prostaglandin $\mathrm{A}_{1} ; 15 \mathrm{~d}-\mathrm{PGJ}_{2}, 15-\mathrm{deoxy} \Delta^{12,14} \mathrm{PGJ}_{2}$; PPAR, peroxisome-proliferator activated receptor; PPRE, PPAR response element; TZD, thiazolinediones

Peroxisome proliferator-activated receptors (PPARs) are members of the nuclear hormone receptor superfamily of ligandactivated transcription factors that are related to retinoid, steroid and thyroid hormone receptors. The PPAR subfamily comprises three members: PPAR- $\alpha$, PPAR- $\beta$ and PPAR- $\gamma$. Two isoforms of PPAR $-\gamma$ are known: PPAR $-\gamma 1$ and PPAR- $\gamma 2$. PPAR $-\gamma 1$ is the major isoform and accounts for approximately $85 \%$ of PPARs in adipose tissue. These isoforms are generated from the same gene by mRNA splicing and differ in their aminoterminal end, with PPAR- $\gamma 2$ having an additional 30 amino acids. The name PPAR is derived from the fact that activation by xenobiotics of PPAR- $\beta$ results in peroxisome proliferation in rodent hepatocytes. Activation of PPAR- $\beta$ or PPAR- $\gamma$, however, does not elicit this response. Most tissues in humans (and rodents) express all three receptor subtypes, although there is considerable variability in the relative expression. PPARs regulate gene expression by binding, as heterodimers with retinoid $\mathrm{X}$ receptors (RXRs), to specific PPAR response elements (PPRE) in the promotor regions of specific target genes, resulting in either the activation or suppression of a specific gene (see Bishop-Bailey, 2000 for review).

The recent development of a novel class of insulin-sensitising drugs, the thiazolidinediones (TZDs), represents a significant advance in antidiabetic therapy. Type II diabetes, also known as noninsulin-dependent diabetes mellitus (NIDDM), is a chronic disease that affects $5-10 \%$ of adults over the age of 30 in most populations. Type II diabetes is characterised by resistance of peripheral tissues to the effects of insulin, which is manifested as a reduction in insulin-stimulated glucose uptake in skeletal muscle and adipose tissue, defective insulindependent suppression of hepatic glucose output and reduced insulin secretion of pancreatic beta cells. There is now good

*Author for correspondence: E-mail: c.thiemermann@qmul.ac.uk Advance online publication: 8 December 2003 evidence that the beneficial effects of TZDs are due to the activation of PPAR- $\gamma$. For instance, the synthetic TZDs were the first class of compounds to be identified as PPAR- $\gamma$ ligands. The insulin-sensitiser rosiglitazone is the most potent and selective PPAR- $\gamma$ agonist and there is a good correlation between the potency of the TZDs as PPAR- $\gamma$ agonist in vitro and their efficacy at lowering glucose levels in vivo. There is less information regarding endogenous ligand(s) for PPAR- $\gamma$. However, the cyclopentanone prostaglandin 15 -deoxy $\Delta^{12,14}$ $\mathrm{PGJ}_{2}\left(15 \mathrm{~d}-\mathrm{PGJ}_{2}\right)$, which is the metabolite of prostaglandin $\mathrm{D}_{2}$, has been suggested to function as an endogenous ligand for PPAR- $\gamma$ (see Bishop-Bailey, 2000 for review).

Several recent, independent investigations provide evidence that TZDs and other ligands of PPAR- $\gamma$ reduce the tissue injury caused by regional myocardial ischaemia and reperfusion in rodents. PPAR- $\gamma 1$ is expressed in the rat heart (Wayman et al., 2002), and various chemically distinct ligands of PPAR- $\gamma$ (including the TZDs rosiglitazone, ciglitazone and pioglitazone, as well as the cyclopentanone prostaglandins $15 \mathrm{~d}-\mathrm{PGJ}_{2}$ and $\mathrm{PGA}_{1}$ ) cause a substantial (30-50\%) reduction of myocardial infarct size in the rat when given prior to the onset of myocardial ischaemia (Thiemermann \& Wayman, 2001; Yue et al., 2001; Wayman et al., 2002). Rosiglitazone also improves the functional recovery of rat hearts obtained from diabetic animals subjected to global ischaemia and reperfusion (Khandoudi et al., 2002). The mechanisms underlying the cardioprotective effects of TZDs are not entirely clear, but may include (i) inhibition of the activation of $\mathrm{NF}-\kappa \mathrm{B}$, (ii) reduced expression of inducible nitric oxide synthase (iNOS), monocyte chemo-attractant protein-1 (MCP-1) and the adhesion molecule ICAM-1, and (iii) inhibition of Jun NH(2)-terminal kinase (Yue et al., 2003; Khandoudi et al., 2002; Wayman et al., 2002). Thus, there is growing evidence that ligands of PPAR $-\gamma$ may be useful in the therapy of conditions associated with inflammation and ischaemia-reperfusion of the heart (e.g. myocardial infarction, heart transplantation, bypass surgery) and inflammation and ischaemia-reperfusion of other 
organs (Takano et al., 2000; Nakajima et al., 2001; Cuzzocrea et al., 2002; 2003; Kon et al., 2002; Naito et al., 2002; Shiojiri et al., 2002; Collin \& Thiemermann, 2003; Enomoto et al., 2003; Sivarajah et al., 2003).

The role of PPAR- $\gamma$ in heart failure is controversial. On the one hand, PPAR- $\gamma$ ligands reduce the hypertrophy caused by mechanical strain in neonatal cardiac myocytes (Yamamoto et al., 2001) and pioglitazone improves left ventricular remodelling in mice hearts subjected to myocardial infarction (Shiomi et al., 2002; discussed below). On the other hand, there is clinical evidence of an increase in the incidence of heart failure in patients with type II diabetes who are treated with TZDs (Delea et al., 2002).

In this issue of the British Journal of Pharmacology, Frantz et al. (2003) have investigated the effects of pioglitazone in a mouse model of heart failure. They report that pioglitazone (single dose of $20 \mathrm{mg} \mathrm{kg}^{-1}$ at day 7 after infarction) had no effect on mortality, left ventricular remodelling, cytokine expression, collagen content or endothelial dysfunction in mice that had been subjected to myocardial infarction prior to onset of treatment with the TZD. In contrast, have recently reported that administration of pioglitazone in mice subjected to infarction $\left(3 \mathrm{mg} \mathrm{kg}^{-1} \mathrm{day}^{-1}\right.$ starting $6 \mathrm{~h}$ after surgery for 4 weeks) significantly reduced left ventricular dysfunction, and this effect was associated with a decrease in myocyte hypertrophy and interstitial fibrosis and a reduced expression of tumour necrosis factor- $\alpha$, transforming growth factor- $\beta$ and MCP-1.

The reasons for the observed differences in the results of the above studies are likely to be due to differences in study design. It is possible that the dose regimen of pioglitazone chosen by was not appropriate, as the authors did administer only a single dose of $20 \mathrm{mg} \mathrm{kg}^{-1}$ pioglitazone on day 7 after occlusion of the coronary artery. In contrast, administered pioglitazone $\left(3 \mathrm{mg} \mathrm{kg}^{-1} \mathrm{day}^{-1}\right)$ for a period of 4 weeks starting immediately after the onset of surgery. The latter strategy has the advantage that the treatment covers any events occurring during the early reperfusion period as well as during the period of cardiac remodelling. Indeed, it is likely that proinflammatory cytokines and other proinflammatory mediators produced in the hours and days after the ischaemic event importantly contribute to the development of left ventricular remodelling. Interestingly, injections of single doses of the PPAR- $\gamma$ ligand $15 \mathrm{~d}-\mathrm{PGJ}_{2}$ are sufficient to reduce the tissue injury associated with acute inflammation (pleurisy), while repetitive injections of this PPAR- $\gamma$ ligand (every $48 \mathrm{~h}$ over weeks) are needed to reduce the tissue injury associated with chronic inflammation (collagen-induced arthritis) (Cuzzocrea et al., 2002). Thus, a continuous administration of TZDs over a prolonged period of time appears to be more suitable to combat more prolonged disease processes, such as the development of left ventricular remodelling and heart failure, than a single bolus administration of the same drug.

The conclusion of that pioglitazone does not reduce left ventricular remodelling and heart failure could have been strengthened if the authors had included data documenting the effects (or lack of effects) of different dose regimen of pioglitazone or if they had been able to document that appropriate dose regimens of other TZDs also do not reduce the degree of heart failure in mice subjected to coronary artery ligation. One could also argue that the degree of heart failure caused in the study by was too severe to allow any treatment to be effective. This argument could be overcome by the inclusion of a 'positive control group' to document that a reduction in the degree of remodelling can indeed be achieved by administration of a single bolus injection of a 'reference drug' at 7 days after coronary artery ligation.

Given the evidence that pretreatment of rodents with ligands of PPAR- $\gamma$ reduces myocardial infarct size, it is likely that any reduction in infarct size would result in an attenuation of the degree of cardiac dysfunction caused by the ischaemic event. Thus, further studies are warranted that compare the effects of TZDs given prior to the onset of ischaemia with those of TZDs given at various times after the onset of reperfusion of the previously ischaemic myocardium. Whether PPAR- $\gamma$ agonists are ultimately able to reduce the degree of left ventricular remodelling following acute myocardial infarction (or not) remains to be seen. Nevertheless, it is interesting to realise that the beneficial effects of TZDs are not limited to insulin-sensitising effects in type II diabetes, but can be observed in a multitude of (animal models of) diseases associated with ischaemia-reperfusion and inflammation (Takano et al., 2000; Nakajima et al., 2001; Cuzzocrea et al., 2002; 2003; Kon et al., 2002; Naito et al., 2002; Shiojiri et al., 2002; Collin \& Thiemermann, 2003; Enomoto et al., 2003; Sivarajah et al., 2003). These anti-inflammatory effects of TZDs in animal models are corroborated by clinical data demonstrating that rosiglitazone reduces the serum levels of the proinflammatory marker c-reactive protein as well as the serum levels of matrix-metalloproteinase-9 in patients with type II diabetes (Haffner et al., 2002).

\section{References}

BISHOP-BAILEY, D. (2000). Peroxisome proliferator-activated receptors in the cardiovascular system. Br. J. Pharmacol., 129, 823-834. COLLIN, M. \& THIEMERMANN, C. (2003). The PPAR-gamma ligand 15-deoxy(Delta12,14) prostaglandin $\mathrm{J}(2)$ reduces the liver injury in endotoxic shock. Eur. J. Pharmacol., 476, 257-258.

CUZZOCREA, S., PISANO, B., DUGO, L., IANARO, A., PATEL, N.S., PAOLA, R.D., GENOVESE, T., CHATTERJEE, P.K., ROSA, M.D., CAPUTI, A.P. \& THIEMERMANN, C. (2003). Rosiglitazone and 15deoxy- $\backslash\{$ Delta $\backslash\} 12,14$-prostaglandin $\mathrm{J} 2$, ligands of the peroxisome proliferator-activat. Br. J. Pharmacol., 140, 366-376.

CUZZOCREA, S., WAYMAN, N.S., MAZZON, E., DUGO, L., DI PAOLA, R., SERRAINO, I., BRITTI, D., CHATTERJEE, P.K., CAPUTI, A.P. \& THIEMERMANN, C. (2002). The cyclopentenone prostaglandin 15-deoxy-Delta(12,14)-prostaglandin $\mathrm{J}(2)$ attenuates the development of acute and chronic inflammation. Mol. Pharmacol., 61, 997-1007.
DEleA, T., HAGIWARA, M., EDElsberG, J \& OSTER, G. (2002). Exposure of glitazones anti-diabetics and risk of heart failure among persons with type 2 diabetes: a retrospective population-based cohort analysis. $J A C C, 39$, abstract 858-3.

ENOMOTO, N., TAKEI, Y., HIROSE, M., KONNO, A., SHIBUYA, T., MATSUYAMA, S., SUZUKI, S., KITAMURA, K.I. \& SATO, N. (2003). Prevention of ethanol-induced liver injury in rats by an agonist of peroxisome proliferator-activated receptor-gamma, pioglitazone. J. Pharmacol. Exp. Ther., 306, 846-854.

FRANTZ, S., HU, K., WIDDER, J., BAYER, B., WITZEL, C.C., SCHMIDT, I., GALUPPO, P., STROTMAN, J., ERTL, G. \& BAUERSACHS, J. (2003). Peroxosome-proliferator activated receptor agonism and left ventricular remodeling in mice with chronic myocardial infarction. Br. J. Pharmacol., 141, 9-14. 
HAFFNER, S.M., GREENBERG, A.S., WESTON, W.M., CHEN, H., WILLIAMS, K. \& FREED, M.I. (2002). Effect of rosiglitazone treatment on nontraditional markers of cardiovascular disease in patients with type 2 diabetes mellitus. Circulation, 106, 679-684.

KHANDOUDI, N., DELERIVE, P., BERREBI-BERTRAND, I., BUCKINGHAM, R.E., STAELS, B. \& BRIL, A. (2002). Rosiglitazone, a peroxisome proliferator-activated receptor-gamma, inhibits the Jun $\mathrm{NH}(2)$-terminal kinase/activating protein 1 pathway and protects the heart from ischemia/reperfusion injury. Diabetes, 51, $1507-1514$

KON, K., IKEJIMA, K., HIROSE, M., YOSHIKAWA, M., ENOMOTO, N., KITAMURA, T., TAKEI, Y. \& SATO, N. (2002). Pioglitazone prevents early-phase hepatic fibrogenesis caused by carbon tetrachloride. Biochem. Biophys. Res. Commun., 291, 55-61.

NAITO, Y., TAKAGI, T., UCHIYAMA, K., HANDA, O., TOMATSURI, N., IMAMOTO, E., KOKURA, S., ICHIKAWA, H., YOSHIDA, N. \& YOSHIKAWA, T. (2002). Suppression of intestinal ischemiareperfusion injury by a specific peroxisome proliferator-activated receptor-gamma ligand, pioglitazone, in rats. Redox Rep., 7, 294-299.

NAKAJIMA, A., WADA, K., MIKI, H., KUBOTA, N., NAKAJIMA, N., TERAUCHI, Y., OHNISHI, S., SAUBERMANN, L.J., KADOWAKI, T., BLUMBERG, R.S., NAGAI, R. \& MATSUHASHI, N. (2001). Endogenous PPAR gamma mediates anti-inflammatory activity in murine ischemia-reperfusion injury. Gastroenterology, 120, 460-469.

SHIOJIRI, T., WADA, K., NAKAJIMA, A., KATAYAMA, K., SHIBUYA, A., KUDO, C., KADOWAKI, T., MAYUMI, T., YURA, Y. \& KAMISAKI, Y. (2002). PPAR gamma ligands inhibit nitrotyrosine formation and inflammatory mediator expressions in adjuvantinduced rheumatoid arthritis mice. Eur. J. Pharmacol., 448, $231-238$.

SHIOMI, T., TSUTSUI, H., HAYASHIDANI, S., SUEMATSU, N., IKEUCHI, M., WEN, J., ISHIBASHI, M., KUBOTA, T., EGASHIRA, K. \& TAKESHITA, A. (2002). Pioglitazone, a peroxisome proliferator-activated receptor-gamma agonist, attenuates left ventricular remodeling and failure after experimental myocardial infarction. Circulation, 106, 3126-3132.
Sivarajah, A., ChATTERJEe, P.K., PATEl, N.S., TODOROVIC, Z., HATTORI, Y., BROWN, P.A., STEWART, K.N., MOTA-FILIPE, H., CUZZOCREA, S. \& THIEMERMANN, C. (2003). Agonists of peroxisome-proliferator activated receptor-gamma reduce renal ischemia/reperfusion injury. Am. J. Nephrol., 23, 267-276.

TAKANO, H., NAGAI, T., ASAKAWA, M., TOYOZAKI, T., OKA, T., KOMURO, I., SAITO, T. \& MASUDA, Y. (2000). Peroxisome proliferator-activated receptor activators inhibit lipopolysaccharide-induced tumor necrosis factor-alpha expression in neonatal rat cardiac myocytes. Circ. Res., 87, 596-602.

THIEMERMANN, C. \& WAYMAN, N.S. (2001). Menarini Academy Cardiovascular Research Awards in Basic Science 2001: ligands of the orphan receptor peroxisome-proliferator activator-gamma reduce myocardial infarct size. Med. Sci. Monit., 7, 787-789.

WAYMAN, N.S., HATTORI, Y., MCDONALD, M.C., MOTA-FILIPE, H., CUZZOCREA, S., PISANO, B., CHATTERJEE, P.K. \& THIEMERMANN, C. (2002). Ligands of the peroxisome proliferator-activated receptors (PPAR-gamma and PPAR-alpha) reduce myocardial infarct size. FASEB J., 16, 1027-1040.

YAMAMOTO, K., OHKI, R., LEE, R.T., IKEDA, U. \& SHIMADA, K. (2001). Peroxisome proliferator-activated receptor gamma activators inhibit cardiac hypertrophy in cardiac myocytes. Circulation, 104, 1670-1675.

YUE, T.L., BAO, W., JUCKER, B.M., GU, J.L., ROMANIC, A.M., BROWN, P.J., CUI, J., THUDIUM, D.T., BOYCE, R., BURNS-KURTIS, C.L., MIRABILE, R.C., ARAVINDHAN, K. \& OHLSTEIN, E.H. (2003). Activation of peroxisome proliferatoractivated receptor-alpha protects the heart from ischemia/reperfusion injury. Circulation, 108, 2393-2399.

YUE, T.L., CHEN, J., BAO, W., NARAYANAN, P.K., BRIL, A., JIANG, W., LYSKO, P.G., GU, J.L., BOYCE, R., ZIMMERMAN, D.M., HART, T.K., BUCKINGHAM, R.E. \& OHLSTEIN, E.H. (2001). In vivo myocardial protection from ischemia/reperfusion injury by the peroxisome proliferator-activated receptor-gamma agonist rosiglitazone. Circulation, 104, 2588-2594.

(Received October 10, 2003 Accepted October 21, 2003) 